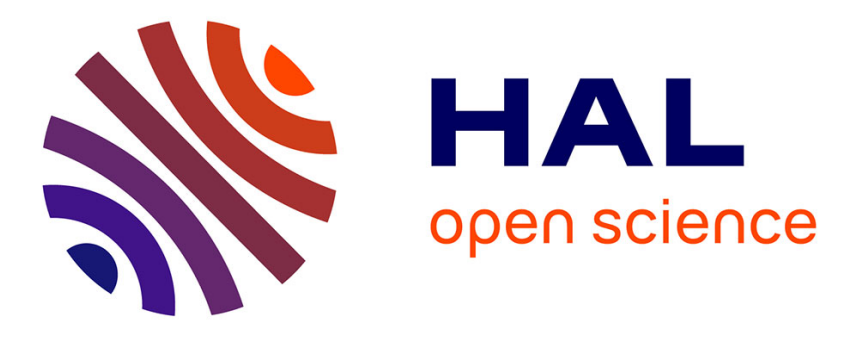

\title{
Synthesis and Complexation Properties Towards Metal Ions of New Tri-substituted Thiacalix[4]arenes
}

Sami Ben Maamar, Natsagma Jadambaa, Francis Vocanson, Faouzi Meganem, Caroline Felix, Isabelle Dumazet-Bonnamour

\section{To cite this version:}

Sami Ben Maamar, Natsagma Jadambaa, Francis Vocanson, Faouzi Meganem, Caroline Felix, et al.. Synthesis and Complexation Properties Towards Metal Ions of New Tri-substituted Thiacalix[4]arenes. Supramolecular Chemistry, 2009, 21 (6), pp.450-454. 10.1080/10610270802195586 . hal-00513534

\author{
HAL Id: hal-00513534 \\ https://hal.science/hal-00513534
}

Submitted on 1 Sep 2010

HAL is a multi-disciplinary open access archive for the deposit and dissemination of scientific research documents, whether they are published or not. The documents may come from teaching and research institutions in France or abroad, or from public or private research centers.
L'archive ouverte pluridisciplinaire HAL, est destinée au dépôt et à la diffusion de documents scientifiques de niveau recherche, publiés ou non, émanant des établissements d'enseignement et de recherche français ou étrangers, des laboratoires publics ou privés. 


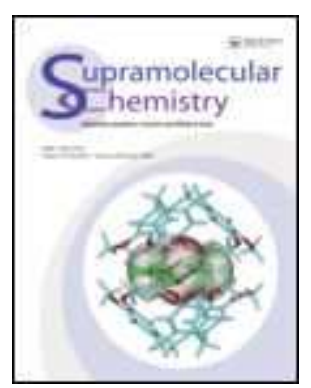

\section{Synthesis and Complexation Properties Towards Metal Ions of New Tri-substituted Thiacalix[4]arenes}

\begin{tabular}{|r|l|}
\hline Journal: & Supramolecular Chemistry \\
\hline Manuscript ID: & GSCH-2008-0027.R1 \\
\hline Manuscript Type: & Full Paper \\
\hline Date Submitted by the \\
Author: & $30-A p r-2008$ \\
\hline Complete List of Authors: & $\begin{array}{l}\text { FELIX, Caroline; Université lyon 1, UFR de chimie } \\
\text { Vocanson, Francis; Université Jean Monnet, UMR 5516 } \\
\text { dumazet-bonnamour, isabelle; Université Lyon 1 }\end{array}$ \\
\hline Keywords: & thiacalix[4]arenes, synthesis, conformation, metal complexation \\
\hline
\end{tabular}

\section{S ScholarONE" \\ Manuscript Central}




\section{Synthesis and Complexation Properties Towards Metal Ions of New Tri-substituted Thiacalix[4]arenes}

S. Ben Maamar ${ }^{a, b}$, N. Jadambaa ${ }^{a}$, F. Vocanson ${ }^{a, c^{*}}$, F. Meganem ${ }^{b}$, C. Felix ${ }^{a}$, I. Bonnamour ${ }^{a}$

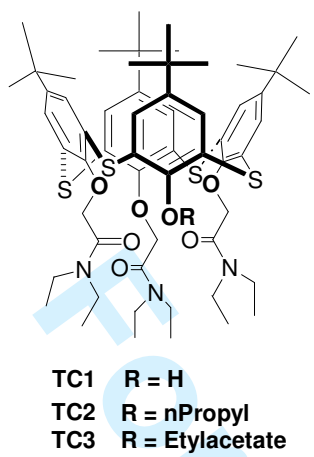

New thiacalix[4]arenes appended with three amide functions have been prepared. The complexation ability of these ligands towards various metal ions $\left(\mathrm{Cd}^{2+}, \mathrm{Pb}^{2+}, \mathrm{Pd}^{2+} ; \mathrm{Ni}^{2+}, \mathrm{Hg}^{2+}, \mathrm{Hg}^{+}, \mathrm{Ag}^{+}, \mathrm{Zn}^{2+}\right.$ and $\left.\mathrm{Cu}^{2+}\right)$ has been investigated by UV-vis absorption. 


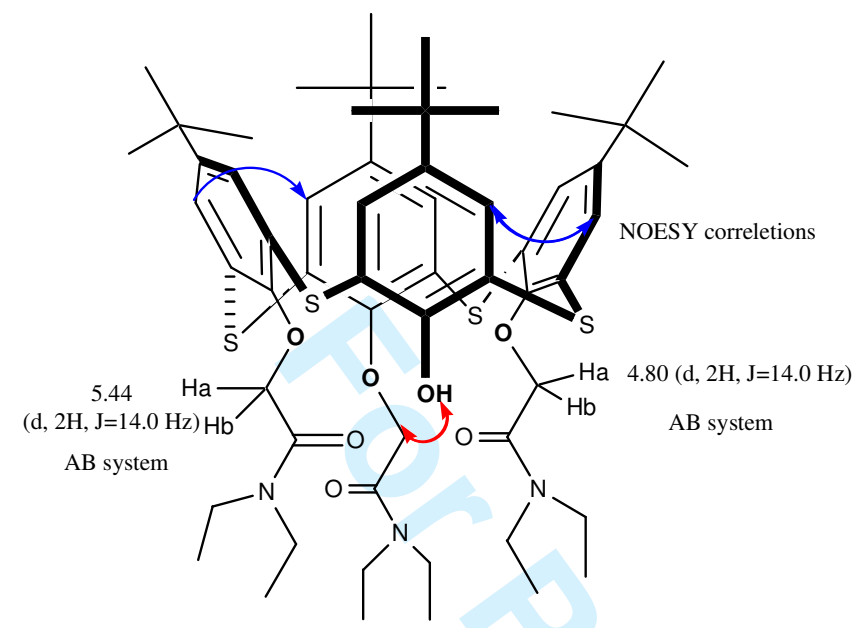

Figure 1. Conformational analysis of TC1.

$\mathrm{CH}_{3} \mathrm{CN}$ resulting from additions of $\mathrm{Pb}\left(\mathrm{NO}_{3}\right)_{2}\left(5 \cdot 10^{-4} \mathrm{M}\right.$ in acetonitrile/water, $\left.3 \mathrm{v} / \mathrm{v}\right)$. 


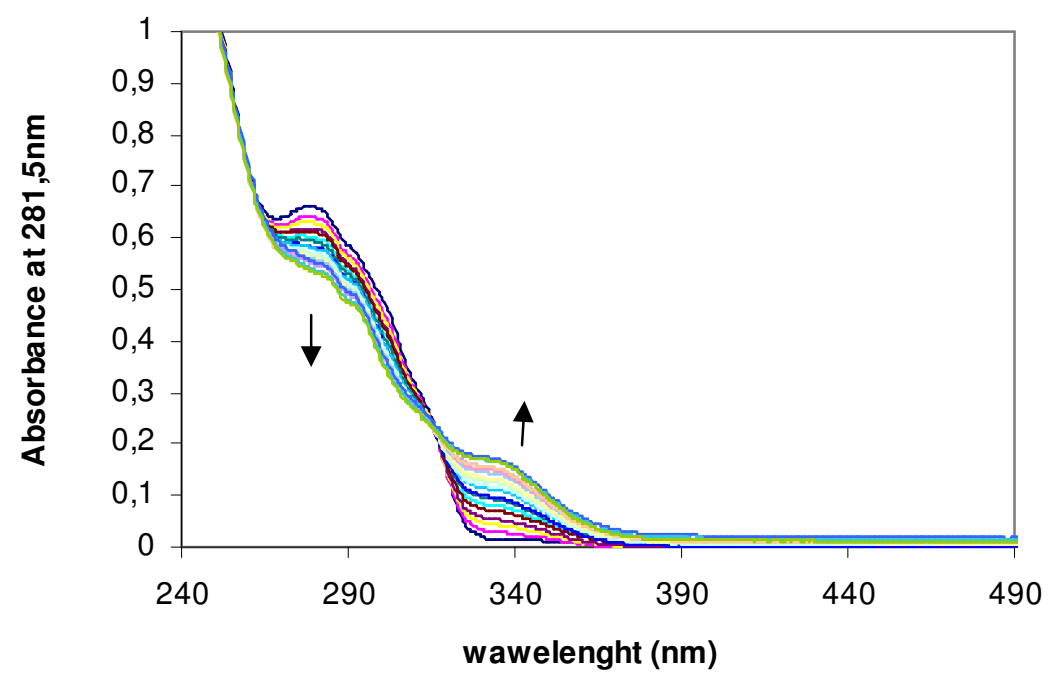

Figure 2. Changes in the absorbance spectrum of a $5.10^{-5} \mathrm{M}$ solution of ligand TC1 in $\mathrm{CH}_{3} \mathrm{CN}$ resulting from additions of $\mathrm{Pb}\left(\mathrm{NO}_{3}\right)_{2}\left(5.10^{-4} \mathrm{M}\right.$ in acetonitrile/water, $\left.3 \mathrm{v} / \mathrm{v}\right)$. 


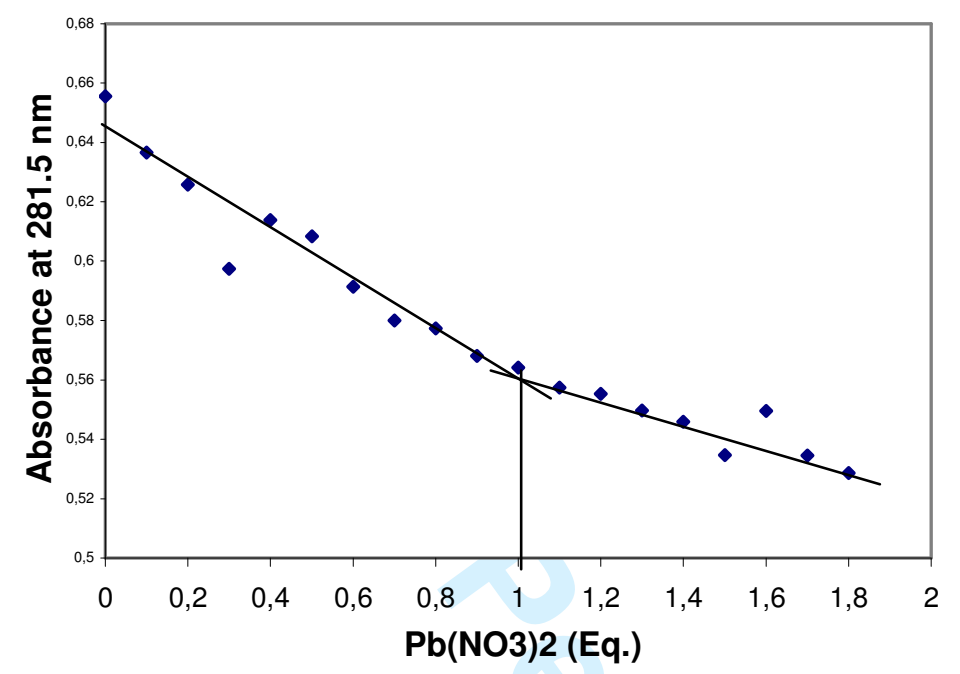

(a) Mole ratio method of $\mathrm{Pb}^{2+}-\mathbf{T C 1}$ mixture

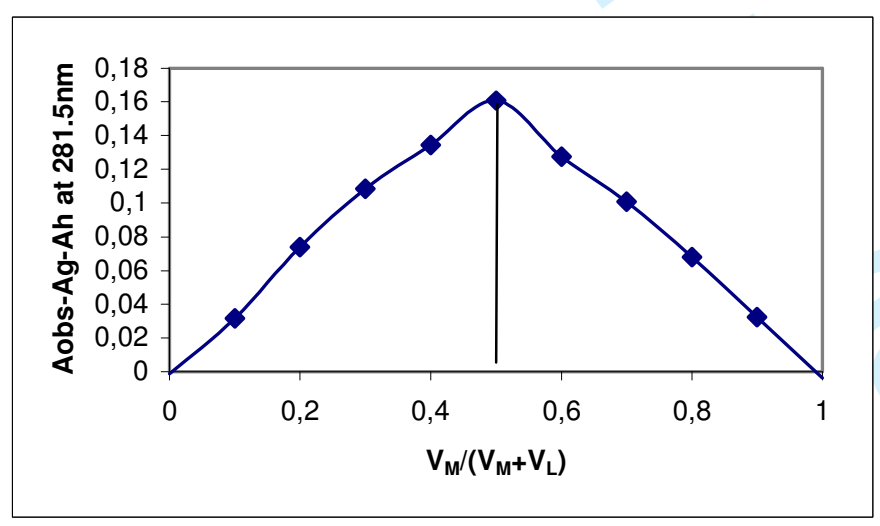

(b) Job plot of the titration of $\mathrm{Pb}^{2+}$ with TC1.

Figure 3. Determination of the stoichiometry of Pb-ligand Complex 

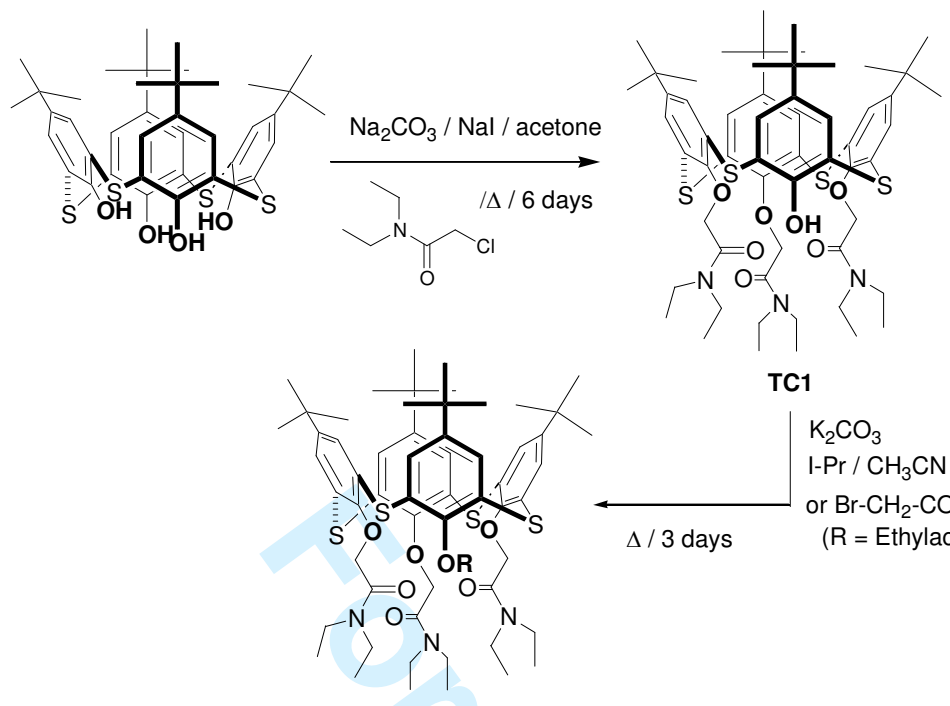

TC1

TC2 $R=n$ Propyl

TC3 $R$ = Etylacetate

Scheme 1. Synthesis of triamide ligand derivatives. 
Supramolecular Chemistry

\title{
Synthesis and Complexation Properties Towards Metal Ions of New Tri-substituted Thiacalix[4]arenes
}

\begin{abstract}
New thiacalix[4]arenes appended with three amide functions have been prepared. Their conformations have been solved thanks to ${ }^{1} \mathrm{H}$ NMR $2 \mathrm{D}$ COSY and NOESY. The complexation ability of these ligands towards various metal ions $\left(\mathrm{Cd}^{2+}, \mathrm{Pb}^{2+}, \mathrm{Pd}^{2+} ; \mathrm{Ni}^{2+}, \mathrm{Hg}^{2+}, \mathrm{Hg}^{+}, \mathrm{Ag}^{+}, \mathrm{Zn}^{2+}\right.$ and $\left.\mathrm{Cu}^{2+}\right)$ has been investigated by $\mathrm{UV}$-vis absorption and the stoichiometry of the metal-ligand complexes was determined.
\end{abstract}

Keywords: thiacalix[4]arene, synthesis, conformation, metal complexation.

\section{Introduction}

Toxic heavy metals like copper, mercury, lead, nickel or cadmium can have a serious impact on the aqueous environment. So, detection and treatment of these toxic metal ions still remain an important topic. In this field, calixarenes, the well known cyclic oligomers of $p$-substituted phenols and formaldehyde, have attracted increased interest. Since the conventional 
calix[4]arenes have poor coordination ability towards metal ions, chemical modifications have taken place by introducing functional groups having metal-binding ability. Recently, a new class of macrocycles named thiacalixarenes has emerged. The presence of sulphur atoms (which possess lone pairs and vacant $3 \mathrm{~d}$ orbitals) instead of methylene bridges opens new possibilities, especially in the field of metal complexation. The parent thiacalix[4]arene was found to extract a wide range of transition metal ions from water, in contrast to classical calix[4]arene (1). From many years, our group was interested in metal ions complexation and extraction (2-4). Hence, we have previously reported the synthesis of a thiacalix[4]arene with tetra-amide functions at the lower rim (4). Extraction experiments have evidenced a remarkable binding ability of this ligand towards a wide range of metal cations.

With the aim of supplementing this study, we wondered about the role of the number of chelating groups. The lower rim functionalization of thiacalix[4]arene is becoming better understood following the work of Lhotak $(5,6)$ and Yamamoto (7). A few articles reports the odd functionalisation of thiacalixarenes. Among them, for example the trimethylation of the hydroxyls of thiacalix[4]arene (5) was described (5) using $\mathrm{K}_{2} \mathrm{CO}_{3}$ in acetonitrile.

In this paper, we describe the preparation of thiacalix[4]arenes substituted with tri-amide functions at the lower rim. The complexation ability of these new ligands towards various metal ions has been investigated by UV-vis titration. The goal of this work is to dispose of a macrocycle which could be grafted on a surface without losing its complexation properties.

\section{Preparation and characterization of the ligands}

The synthetic route for the ligands TC1-3 is depicted in Scheme 1. The O-alkylation of the lower rim of the parent $p$-tert-butylthiacalix[4] arene was achieved by action of $\mathrm{Na}_{2} \mathrm{CO}_{3}$ (3eq.) in acetone in presence of $\mathrm{NaI}$, followed by 2 -chloro- $N, N$-diethylacetamide. The reaction was refluxed three days and the crude product was purified by chromatography on silica gel to 
afford the pure TC1. ${ }^{1} \mathrm{H}$ and ${ }^{13} \mathrm{C}$ NMR spectra of $\mathbf{T C 1}$ in $\mathrm{CDCl}_{3}$ showed the presence of the expected tri-amide derivative. However, it was difficult to determine the conformation of TC1. To complete the structural analysis, 2D COSY and NOESY experiments were performed. The ${ }^{1} \mathrm{H}$ NMR shows two doublets and one singlet for the $\mathrm{O}-\mathrm{CH}_{2}-\mathrm{C}=\mathrm{O}$ signal. The 2D COSY confirms the presence of an $\mathrm{AB}$ system for two $\mathrm{O}-\mathrm{CH}_{2}-\mathrm{C}=\mathrm{O}$ groups and a singlet for the third one (Figure 1). This $\mathrm{AB}$ system results from the rigidity of the calixarene conformation and of the prochirality of two of the $\mathrm{CH}_{2}$ groups. The 2D NOESY shows correlation spots between the aromatic hydrogens of neighboring phenyl moieties. A correlation spot is also present between one $\mathrm{O}-\mathrm{CH}_{2}-\mathrm{C}=\mathrm{O}$ group (corresponding to the singlet signal) and the $\mathrm{OH}$ function (Figure 1). With the sight of these results, we can conclude that the tri-substituted thiacalix[4]arene TC1 adopts a cone conformation in solution. Then the derivatization of the thiacalixarene TC1 was researched to establish the influence of the substitution of the phenolic group on the complexation of metallic cations. At first TC1 was alkylated with 1-iodopropane in refluxing acetonitrile in the presence of $\mathrm{K}_{2} \mathrm{CO}_{3}$ as a base. The desired product TC2 bearing three amide group and one propyl group was obtained after chromatographic separation. TC1 was also alkylated with ethylbromoacetate in refluxing acetone in the presence of $\mathrm{K}_{2} \mathrm{CO}_{3}$ as a base. The desired product TC3 bearing three amide group and one ethylacetate group was also obtained after chromatographic separation. The compounds TC2 and TC3 were identified by ${ }^{1} \mathrm{H}$ and ${ }^{13} \mathrm{C}$ NMR, and, ES-MS. The NMR analysis showed that the cone conformation was conserved for the two macrocyclic derivatives.

\section{Complexation study}

The UV-vis spectra of TC1-3 show characteristic bands between 290 and $340 \mathrm{~nm}$ in $\mathrm{CH}_{3} \mathrm{CN} /$ $\mathrm{H}_{2} \mathrm{O}(3 \mathrm{v} / \mathrm{v})$. Complexation properties of TC1-3 were studied towards various metal salts 
$\left(\mathrm{Cd}^{2+}, \mathrm{Pb}^{2+}, \mathrm{Pd}^{2+}, \mathrm{Ni}^{2+}, \mathrm{Hg}^{2+}, \mathrm{Hg}^{+}, \mathrm{Ag}^{+}, \mathrm{Zn}^{2+}\right.$ and $\left.\mathrm{Cu}^{2+}\right)$ by $\mathrm{UV}$-vis titrations. In all cases, upon addition of metal cations solutions to a solution of TC1-3, spectra undergo clear changes and show the presence of isobestic points indicating the existence of complex species. The addition of aliquots of $\mathrm{Pb}^{2+}$ (from 0.2 to 1 equivalent) to a solution of $\mathbf{T C 1}$ in a mixture of acetonitrile and water ( $3 \mathrm{v} / \mathrm{v})$ led to a decrease in the absorption bands at $280 \mathrm{~nm}$ and to the appearance of a new absorption band centred at $335.5 \mathrm{~nm}$ that is characteristic of a MLCT (Metal-Ligand Charge Transfer) band between $\mathrm{Pb}^{2+}$ and the nitrogen and oxygen atoms of the amide functions on the macrocycle (Figure 2). The isobestic point centred at $315.5 \mathrm{~nm}$ shows the formation of a new complex. Similar effects were observed upon addition of $\mathrm{Ag}^{+}, \mathrm{Cd}^{2+}$, $\mathrm{Hg}^{+}, \mathrm{Zn}^{2+}, \mathrm{Pd}^{2+}$ and $\mathrm{Cu}^{2+}$. Upon addition of cations solutions, we can observe in all cases a hypsochromic effect of the band at $285 \mathrm{~nm}$ and MLCT bands.

The stoichiometry of metal-ligand (M-L) complexes was determined both by the molar ratio (8) and the Job plot (9) methods (Figure 3). The results are given in Table 1. They indicate a 1:1 stoichiometry for five complexes $\left(\mathrm{Ag}^{+}, \mathrm{Cd}^{2+}, \mathrm{Pb}^{2+}, \mathrm{Ni}^{2+}, \mathrm{Pd}^{2+}\right)$ in accordance with the literature data (10). We observed the formation of $\mathrm{M}_{\mathrm{x}}-\mathrm{L}_{\mathrm{y}}$ complexes with $\mathrm{Hg}^{+}, \mathrm{Cu}^{2+}$ and $\mathrm{Zn}^{2+}$. It should be outlined that no complexation was observed for TC1 with $\mathrm{Hg}^{2+}$ For comparison, the complexation of mercury salts by the tetra-amide-thiacalix[4]arene derivative was studied : this macrocycle does not retain $\mathrm{Hg}^{+}(11)$ ions but a complex is obtained between $\mathrm{Hg}^{2+}$ ions and the receptor in acetonitrile as solvent (5). Complexation properties of TC2 are reported in Table 1. ML type complexes are obtained for $\mathrm{Ag}^{+}, \mathrm{Zn}^{2+}, \mathrm{Pb}^{2+}, \mathrm{Ni}^{2+}$ and $\mathrm{Pd}^{2+}$. Compared with the ligand TC1, we can highlight the formation of a monovalent complex with $\mathrm{Zn}^{2}$ No complexation occurs with $\mathrm{Hg}^{+}$whereas the addition of $\mathrm{Hg}^{2+}$ ions in a solution of TC2 leads to the formation of a multivalent complex. The ligand TC3, bearing an ester group instead of a propyl chain, affords ML type complexes with $\mathrm{Cd}^{2+}, \mathrm{Zn}^{2+}, \mathrm{Pb}^{2+}, \mathrm{Hg}^{2+}$ and $\mathrm{Pd}^{2+}$. $\mathrm{A} \mathrm{ML}_{2}$ type complex is observed with $\mathrm{Ag}^{+}$. 
The stability constants $\mathrm{K}$ are defined as the concentration ratio [Eq. (1)] :

(1) $\quad K=\frac{[M L]}{[M][L]}$

$\mathrm{K}$ can be correlated to the change in absorbance due to the formation of the ML complex. Further modifications of the Benesi -Hildebrand method (12) result in an equation where a double reciprocal plot can be made with $1 / \Delta \mathrm{A}$ as a function of $1 /[\mathrm{M}]$ [Eq.(2)] :

(2) $\frac{1}{\Delta \mathrm{A}}=\left[\frac{1}{\Delta \varepsilon[\mathrm{L}]_{0} \mathrm{~K}}\right]\left[\frac{1}{[\mathrm{M}]}\right]+\frac{1}{\Delta \varepsilon[\mathrm{L}]_{0}}$

The logarithms of the stability constants $(\log K)$ are collected in Table 2 Values of the stability constants seem to indicate that the cation $\mathrm{Cd}^{2+}$ is strongly complexed with ligand TC1 undoubtedly because of its great affinity for $\mathrm{N}$ and $\mathrm{O}$ atoms. TC2 and TC3 ligands exhibit affinity in the same range for all metal cations. This indicates that the introduction of an ester function instead of a propyl chain does not affect their binding ability. These results also show that it will be possible to introduce on the ligand TC1, a spacer with a terminal function as silane or thiol allowing the grafting on a surface without lost of recognition. On this way TC1 is more interesting than the thiacalixarene with the four tetra-amide functions.

\section{Conclusion}

New thiacalix[4]arene derivatives appended with three amide functions have been prepared and their conformation described. The complexation ability of these ligands towards various metal ions has been investigated by UV-vis absorption. These receptors exhibit similar 


\section{Experimental section}

General methods. Solvents were purified and dried by standard methods prior to use. All reactions were carried out under nitrogen. Column chromatography was performed with silica gel $60(0.040-0.063 \mathrm{~nm})$. Melting points are uncorrected. ${ }^{1} \mathrm{H}$ NMR and ${ }^{13} \mathrm{C}$ NMR spectra were obtained at 300.13 and $75 \mathrm{MHz}\left(\mathrm{CDCl}_{3}\right.$, TMS as internal standard, chemical shifts in ppm, $\mathrm{J}$ in Hertz). Mass spectra were obtained by electrospray technique (positive mode).

\section{$5,11,17,23-t e t r a-p$-tert-butyl-25,26,27- $N, N$-diethylaminocarbonyl-28-hydroxythia-}

calix[4]arene TC1 (cone conformer). To a solution of $0.4 \mathrm{~g}\left(5.55 .10^{-4} \mathrm{~mol}\right)$ of p-tertbutylthiacalix[4]arene and $0.176 \mathrm{~g}\left(1.66 .10^{-3} \mathrm{~mol}\right)$ of $\mathrm{Na}_{2} \mathrm{CO}_{3}$ in acetone $(60 \mathrm{~mL})$, under nitrogen flux, was added $0.25 \mathrm{~g}\left(1.66 .10^{-3} \mathrm{~mol}\right)$ of $\mathrm{NaI}$ and $0.24 \mathrm{~mL}\left(1.66 .10^{-3} \mathrm{~mol}\right)$ of 2chloro- $N, N$-diethylacetamide. The mixture was refluxed for three days. The solvent was removed under vacuum. To the residue was added $\mathrm{CHCl}_{3}(40 \mathrm{~mL})$. The organic layer was sepa- 
rated, washed with water $(2 \times 20 \mathrm{~mL})$ and dried over $\mathrm{Na}_{2} \mathrm{SO}_{4}$. After removal of the solvent, the residue was purified by chromatography on silica gel $(0.04-0.063 \mathrm{~mm}$ from Merck; eluted with heptane $/ \mathrm{CHCl}_{3}$ 1:1) to afford pure TC1 (286 mg, $\left.48 \%\right) .{ }^{1} \mathrm{H} \mathrm{NMR}\left(300 \mathrm{MHz}, \mathrm{CDCl}_{3}\right)$ : $\delta=9.18(\mathrm{~s}, \mathrm{H}, \mathrm{Ar}-\mathrm{OH}), 7.53(\mathrm{~s}, 2 \mathrm{H}, \mathrm{Ar}-H), 7.38(\mathrm{~s}, 2 \mathrm{H}, \mathrm{Ar}-H), 7.12(\mathrm{~s}, 4 \mathrm{H}, \mathrm{Ar}-H), 5.54(\mathrm{~s}$, $\left.2 \mathrm{H}, \mathrm{Ar}-\mathrm{O}-\mathrm{CH}_{2}-\mathrm{CO}-\right), 5.44$ (d, $2 \mathrm{H}$ (AB system), ${ }^{2} \mathrm{~J}=14.0$, Ar-O-CH$\left.-\mathrm{CO}-\right), 4.82$ (d, 2H (AB system), ${ }^{2} \mathrm{~J}=14.0$, Ar-O-CH$\left.-\mathrm{CO}-\right), 3.51-3.34\left(\mathrm{~m}, 12 \mathrm{H},-\mathrm{CO}-\mathrm{N}\left(\mathrm{CH}_{2}-\mathrm{CH}_{3}\right)_{2}\right), 1.32-0.94$ (m, 54H, $\left.\mathrm{Ar}-\mathrm{C}\left(\mathrm{CH}_{3}\right)_{3},-\mathrm{CO}-\mathrm{N}\left(\mathrm{CH}_{2}-\mathrm{CH}_{3}\right)_{2}\right) .{ }^{13} \mathrm{C} \mathrm{NMR}\left(75 \mathrm{MHz}, \mathrm{CDCl}_{3}\right): \delta=168.70$ and 167.72 $\left(-\mathrm{CH}_{2}-\mathrm{CO}-\mathrm{N}-\right), 157.28$ and $157.83(\mathrm{ArC}-\mathrm{O}), 147.12,145.57$ et $142.03\left(\mathrm{Ar}-\mathrm{C}\left(\mathrm{CH}_{3}\right)_{3}\right), 135.53$, 134.48 and $133.37(\mathrm{ArC}-\mathrm{H}), 129.42$ and $122.14(\mathrm{ArC}-\mathrm{S}), 72.71$ and $69.39\left(\mathrm{Ar}-\mathrm{O}-\mathrm{CH}_{2}-\mathrm{CO}-\right)$, 41.37 and $40.17\left(-\mathrm{CO}-\mathrm{N}\left(\mathrm{CH}_{2}-\mathrm{CH}_{3}\right)_{2}\right), 34.39\left(\mathrm{Ar}-\mathrm{C}\left(\mathrm{CH}_{3}\right)_{3}\right), 31.67\left(\mathrm{Ar}-\mathrm{C}\left(\mathrm{CH}_{3}\right)_{3}\right), 14.82$ and $13.56\left(\mathrm{CO}-\mathrm{N}\left(\mathrm{CH}_{2}-\mathrm{CH}_{3}\right)_{2}\right)$. ES-MS. (positive mode) : mass $(\mathrm{m} / \mathrm{z})=1060[\mathrm{M}+\mathrm{H}]^{+}, 1082.4$ $[\mathrm{M}+\mathrm{Na}]^{+} . \mathrm{Mp}=138{ }^{\circ} \mathrm{C}$.

\section{$5,11,17,23-$ tetra-p-tert-butyl-25,26,27-27- $N, N$-diethylaminocarbonyl-28-propyloxythia-}

calix[4]arene TC2 (cone conformer). To a solution of $0.1 \mathrm{~g}(0.094 \mathrm{mmol})$ of TC1 and 0.065 $\mathrm{g}(0,471 \mathrm{mmol})$ of $\mathrm{K}_{2} \mathrm{CO}_{3}$ in acetonitrile $(5 \mathrm{~mL})$, under nitrogen flux, was added $0.092 \mathrm{~mL}$ (0,943 mmol) of 1-iodopropane. The mixture was refluxed for three days. The solvent was removed under vacuum. To the residue was added $\mathrm{CHCl}_{3}(10 \mathrm{~mL})$ and an aqueous solution of $\mathrm{HCl} 1 \mathrm{~N}(10 \mathrm{~mL})$. The organic layer was separated, washed with water $(3 \times 10 \mathrm{~mL})$ and dried over $\mathrm{Na}_{2} \mathrm{SO}_{4}$. After removal of the solvent, the residue was purified by chromatography on silica gel (0.04-0.063 mm from Merck; eluted with heptane $\left./ \mathrm{CHCl}_{3} 60: 40\right)$ to afford pure TC2 $(23 \mathrm{mg} ; 22 \%)$ as white powder. ${ }^{1} \mathrm{H}$ NMR $\left(300 \mathrm{MHz}, \mathrm{CDCl}_{3}\right): \delta=7.43$ and $7.45(\mathrm{~d}, 4 \mathrm{H}$, Ar-H), $7.11(\mathrm{~s}, 4 \mathrm{H}, \mathrm{Ar}-\mathrm{H}), 5.45$ (s, 2H, O-CH$\left.{ }_{2}-\mathrm{CO}-\mathrm{N}\left(\mathrm{CH}_{2}-\mathrm{CH}_{3}\right)_{2}\right), 5.04$ (s, 4H, 2 -O-CH $\mathrm{CH}_{2}^{-}$ $\left.\mathrm{CO}-\mathrm{N}\left(\mathrm{CH}_{2}-\mathrm{CH}_{3}\right)_{2}\right), 4.28\left(\mathrm{t}, 2 \mathrm{H},{ }^{3} \mathrm{~J}=7.72, \mathrm{O}-\mathrm{CH}_{2}-\mathrm{CH}_{2}-\mathrm{CH}_{3}\right), 3.36-3.54\left(\mathrm{~m}, 12 \mathrm{H}, 3 \mathrm{O}-\mathrm{CH}_{2}-\right.$ $\left.\mathrm{CO}-\mathrm{N}\left(\mathrm{CH}_{2}-\mathrm{CH}_{3}\right)_{2}\right), 1.94-1.97\left(\mathrm{~m}, 2 \mathrm{H}, \mathrm{O}-\mathrm{CH}_{2}-\mathrm{CH}_{2}-\mathrm{CH}_{3}\right), 1.04,1.16$ and 1.25 (m, $57 \mathrm{H}$, O- 
$\mathrm{CH}_{2}-\mathrm{CH}_{2}-\mathrm{CH}_{3}, 3 \mathrm{O}-\mathrm{CH}_{2}-\mathrm{CO}-\mathrm{N}\left(\mathrm{CH}_{2}-\mathrm{CH}_{3}\right)_{2}$ and $\left.\mathrm{Ar}-\mathrm{C}\left(\mathrm{CH}_{3}\right)_{3}\right) .{ }^{13} \mathrm{C} \mathrm{NMR}\left(75 \mathrm{MHz}, \mathrm{CDCl}_{3}\right): \delta$ $=167.52\left(\mathrm{Ar}-\mathrm{O}-\mathrm{CH}_{2}-\underline{C} \mathrm{O}-\right), 158.01(\mathrm{Ar} \underline{C}-\mathrm{O}), 146.92\left(\operatorname{Ar} \underline{C}-\mathrm{C}\left(\mathrm{CH}_{3}\right)_{3}\right), 134.85,135.57$ and 135.96 (Ar $\underline{C}-\mathrm{H}), 128.50,129.17$ and 130.96 (Ar $\underline{C}-\mathrm{S}-), 70.28$ and $72.69\left(\mathrm{Ar}-\mathrm{O}-\underline{C} \mathrm{H}_{2}-\right), 40.26$, 41.56 and $41.78\left(\mathrm{O}-\mathrm{CH}_{2}-\mathrm{CO}-\mathrm{N}\left(\underline{\mathrm{C}} \mathrm{H}_{2}-\mathrm{CH}_{3}\right)_{2}\right), 34.41$ and $34.57\left(\mathrm{Ar}-\underline{\mathrm{C}}\left(\mathrm{CH}_{3}\right)_{3}\right), 31.48,31.67$ and $31.83\left(\mathrm{Ar}-\mathrm{C}\left(\underline{\mathrm{C}} \mathrm{H}_{3}\right)_{3}\right), 24.23\left(\mathrm{O}-\mathrm{CH}_{2}-\underline{C} \mathrm{H}_{2}-\mathrm{CH}_{3}\right), 14.52$ and $14.89\left(\mathrm{O}-\mathrm{CH}_{2}-\mathrm{CO}-\mathrm{N}\left(\mathrm{CH}_{2}-\underline{C} \mathrm{H}_{3}\right)_{2}\right)$, $13.44\left(\mathrm{O}-\mathrm{CH}_{2}-\mathrm{CH}_{2}-\mathrm{CH}_{3}\right)$. ES-MS. (positive mode): mass $(\mathrm{m} / \mathrm{z})=1102.5[\mathrm{M}+\mathrm{H}]^{+}, 1124.5$ $[\mathrm{M}+\mathrm{Na}]^{+} . \mathrm{Mp}=200{ }^{\circ} \mathrm{C}$.

\section{$5,11,17,23$-tetra-p-tert-butyl-25,26,27- $N, N$-diethylaminocarbonyl-28-ethoxycarbonylthia-}

calix[4]arene TC3 (cone conformer). To a solution of $0.15 \mathrm{~g}(0.141 \mathrm{mmol})$ of TC1 and 0.011 $\mathrm{g}(0.08 \mathrm{mmol})$ of $\mathrm{K}_{2} \mathrm{CO}_{3}$ in acetone $(5 \mathrm{~mL})$, under nitrogen flux, was added $0.031 \mathrm{~mL}(0,283$ mmol) of ethylbromoacetate. The mixture was refluxed for three days. The solvent was removed under vacuum. To the residue was added $\mathrm{CHCl}_{3}(20 \mathrm{~mL})$ and an aqueous solution of $\mathrm{HCl} 1 \mathrm{~N}(10 \mathrm{~mL})$. The organic layer was separated, washed with water $(3 \times 10 \mathrm{~mL})$ and dried over $\mathrm{Na}_{2} \mathrm{SO}_{4}$. After removal of the solvent, the residue was purified by chromatography on silica gel (0.04-0.063 mm from Merck; eluted with heptane $\left./ \mathrm{CHCl}_{3} 60: 40\right)$ to afford pure $\operatorname{TC3}(81 \mathrm{mg} ; 50 \%)$ as white powder. ${ }^{1} \mathrm{H}$ NMR $\left(300 \mathrm{MHz}, \mathrm{CDCl}_{3}\right): \delta=7.36,7.52$ and 7.64 (m, 6H, Ar- $H$ ), 7 (s, 2H, Ar- $H), 4.73,4.98$ and 5.37 (m, 8H, 3 O- $\mathrm{CH}_{2}-\mathrm{CO}-\mathrm{N}\left(\mathrm{CH}_{2}-\mathrm{CH}_{3}\right)_{2}$ and $\mathrm{O}-\mathrm{CH}_{2}-\mathrm{CO}-\mathrm{O}-\mathrm{CH}_{2}-\mathrm{CH}_{3}$ ), 4.21 (q, $2 \mathrm{H},{ }^{3} \mathrm{~J}=7.32, \mathrm{O}-\mathrm{CH}_{2}-\mathrm{CO}-\mathrm{O}-\mathrm{CH}_{2}-\mathrm{CH}_{3}$ ), 3.21 and 3.41 (m, $\left.12 \mathrm{H}, 3 \mathrm{O}-\mathrm{CH}_{2}-\mathrm{CO}-\mathrm{N}\left(\mathrm{CH}_{2}-\mathrm{CH}_{3}\right)_{2}\right), 1.10,1.18,1.25,1.28$ and 1.31 (m, 57H, $3 \mathrm{O}-\mathrm{CH}_{2}-\mathrm{CO}-$ $\mathrm{N}\left(\mathrm{CH}_{2}-\mathrm{CH}_{3}\right)_{2}, \mathrm{Ar}-\mathrm{C}\left(\mathrm{CH}_{3}\right)_{3}$ and $\left.\mathrm{O}-\mathrm{CH}_{2}-\mathrm{CO}-\mathrm{O}-\mathrm{CH}_{2}-\mathrm{CH}_{3}\right) .{ }^{13} \mathrm{C} \mathrm{NMR}\left(75 \mathrm{MHz}, \mathrm{CDCl}_{3}\right): \delta=$ 166.43 and 167.29 (Ar-O-CH$-\mathrm{CO}-), 156.03$ and $158.44(\mathrm{ArC}-\mathrm{O}), 149.82\left(\mathrm{Ar}-\mathrm{C}\left(\mathrm{CH}_{3}\right)_{3}\right)$, 136.80, 136.99 and 137.02 (ArC-H), 128.32, 130.43 and $130.94(\mathrm{ArC}-\mathrm{S}-), 71.74$ and 75 (Ar$\left.\mathrm{O}-\mathrm{CH}_{2}-\right), 61.74\left(\mathrm{O}-\mathrm{CH}_{2}-\mathrm{CO}-\mathrm{O}-\mathrm{CH}_{2}-\mathrm{CH}_{3}\right), 40.44,41.44$ and $41.92\left(\mathrm{O}_{-} \mathrm{CH}_{2}-\mathrm{CO}-\mathrm{N}\left(\mathrm{CH}_{2}-\right.\right.$ $\left.\left.\mathrm{CH}_{3}\right)_{2}\right), 34.83\left(\mathrm{Ar}-\mathrm{C}\left(\mathrm{CH}_{3}\right)_{3}\right), 31.32$ and $31.52\left(\mathrm{Ar}-\mathrm{C}\left(\mathrm{CH}_{3}\right)_{3}\right), 14.72\left(\mathrm{O}-\mathrm{CH}_{2}-\mathrm{CO}-\mathrm{O}-\mathrm{CH}_{2}-\mathrm{CH}_{3}\right)$, 
13.40 and 14.57 (3 O- $\left.\mathrm{CH}_{2}-\mathrm{CO}-\mathrm{N}\left(\mathrm{CH}_{2}-\mathrm{CH}_{3}\right)_{2}\right)$. ES-MS. (positive mode): $\operatorname{mass}(\mathrm{m} / \mathrm{z})=1146,4$ $[\mathrm{M}+\mathrm{H}]^{+}, 1168,4[\mathrm{M}+\mathrm{Na}]^{+} . \mathrm{Mp}=215^{\circ} \mathrm{C}$.

Complexation. The stability constants $\mathrm{K}$ defined as the concentration ratio $[\mathrm{ML}] /([\mathrm{M}][\mathrm{L}])$ (where $\mathrm{M}=$ cation and $\mathrm{L}=$ ligand) were determined at $18{ }^{\circ} \mathrm{C}$, in acetonitrile or a mixture of acetonitrile/water $(3 \mathrm{v} / \mathrm{v})$ by UV absorption spectrophotometry. The spectra were recorded on a Shimadzu UV-2401-PC. The procedure consisted in adding increasing amounts of metallic salts $\left(5.10^{-4} \mathrm{M}\right)$ to a solution of PC1-3 $\left([\mathbf{P C 1}-3]=5.10^{-5} \mathrm{M}\right)$. The metal salts used were chlorides, perchlorates, nitrates or trifluoroacetates according to their solubility in the solvents used. The following salts were used in pure acetonitrile : $\mathrm{Cd}\left(\mathrm{ClO}_{4}\right)_{2} \cdot \mathrm{H}_{2} \mathrm{O}, \mathrm{CF}_{3} \mathrm{COOAg}$, $\mathrm{Zn}\left(\mathrm{ClO}_{4}\right)_{2} \cdot 6 \mathrm{H}_{2} \mathrm{O}, \mathrm{Cu}\left(\mathrm{ClO}_{4}\right)_{2} \cdot 6 \mathrm{H}_{2} \mathrm{O}, \mathrm{PdCl}_{2},\left(\mathrm{CF}_{3} \mathrm{COO}\right)_{2} \mathrm{Hg}$. In a mixture of acetonitrile/water $(3 \mathrm{v} / \mathrm{v})$ the following salts were used : $\mathrm{Pb}\left(\mathrm{NO}_{3}\right)_{2}, \mathrm{NiCl}_{2} \cdot 6 \mathrm{H}_{2} \mathrm{O}, \mathrm{Hg}\left(\mathrm{ClO}_{4}\right)_{2} \cdot 4 \mathrm{H}_{2} \mathrm{O}$.

\section{References}

(1) Iki, I.; Morohashi, N.; Narumi, F.;Miyano, S. Bull. Chem. Soc. Jpn. 1998, 71, 1597.

(2) Halouani, H.; Dumazet-Bonnamour, I.; Perrin, M.; Lamartine, R. J. Org. Chem. 2004, 69, 6521.

(3) Halouani, H.; Dumazet-Bonnamour, I.; Duchamp, C.; Bavoux, C.; Elhinger, N.; Perrin, M.; Lamartine, R. Eur. J. Org. Chem. 2002, 4202.

(4) Lamartine, R.; Bavoux, C.; Vocanson, F.; Martin, A.; Senlis, G.; Perrin, M. Tetrahedron Lett. 2001, 42, 1021.

(5) Lhotak, P. Eur. J. Org. Chem. 2004, 1675.

(6) Lhotak, P.; Kaplanek, L.; Stibor, I.; Lang, J.; Dvorakova, H.; Hrabal, R.; Sykora, J. Tetrahedron Lett. 2000, 41, 9339.

(7) Yamamoto, T.; Zhang, F.; Kumaru, K.; Yamamoto, H. J. Incl. Phenom. 2002, 42, 51. 
(8) Yoe, J. H.; Harvey, A. E. J. Am. Chem. Soc. 1948, 70, 648.

(9) (a) Job, P. Anal. Chem. 1928, 9, 113. (b) Gil, V. M. S.; Oliveira, N. C. J. Chem. Ed. 1990, 67, 473.

(10) Bouhroum, S.; Arnaud-Neu, F.; Asfari, Z.; Vicens, J. J. Supramol. Chem. 2005, 17, 629.

(11) S. Ben Maamar, unpublished results..

(12) K. Hirose J. Incl. Phenom. Macrocycl. Chem. 2001, 39, 193.

(13) Zaghbani, A.; Tayeb, R.; Dhahbi, M.; Hidalgo, M.; Vocanson, F.; Bonnamour, I.; Seta, P.; Fontas, C. Sep. Purif. Technol. 2007, 57, 374. 
Table 1. Stoichiometry of Metal-Ligand complexes.

\begin{tabular}{cccccccccc}
\hline & $\mathrm{Cd}^{2+}$ & $\mathrm{Pd}^{2+}$ & $\mathrm{Pb}^{2+}$ & $\mathrm{Hg}^{+}$ & $\mathrm{Hg}^{2+}$ & $\mathrm{Zn}^{2+}$ & $\mathrm{Cu}^{2+}$ & $\mathrm{Ni}^{2+}$ & $\mathrm{Ag}^{+}$ \\
\hline TC1 & $\mathrm{ML}$ & $\mathrm{ML}$ & $\mathrm{ML}$ & $a$ & $b$ & $a$ & $a$ & $\mathrm{ML}$ & $\mathrm{ML}$ \\
TC2 & $a$ & $\mathrm{ML}$ & $\mathrm{ML}$ & $b$ & $a$ & $\mathrm{ML}$ & $a$ & $\mathrm{ML}$ & $\mathrm{ML}$ \\
TC3 & $\mathrm{ML}$ & $\mathrm{ML}$ & $\mathrm{ML}$ & $b$ & $\mathrm{ML}$ & $\mathrm{ML}$ & $a$ & $a$ & $\mathrm{ML}_{2}$ \\
\hline
\end{tabular}

(a) $\mathrm{M}_{\mathrm{x}}-\mathrm{L}_{\mathrm{y}}$ complexes are observed. (b) no complexation was observed. 
Table 2. Stability constants of (1:1) Metal-Ligand complexes. $\log K(\lambda(n m))$.

\begin{tabular}{cccccccc}
\hline & $\mathrm{Cd}^{2+}$ & $\mathrm{Pd}^{2+}$ & $\mathrm{Pb}^{2+}$ & $\mathrm{Hg}^{2+}$ & $\mathrm{Zn}^{2+}$ & $\mathrm{Ni}^{2+}$ & $\mathrm{Ag}^{+}$ \\
\hline TC1 & 8.04 & 2.69 & 4.51 & - & - & 4.42 & 4.14 \\
& $(281.5)$ & $(244.5)$ & $(281.5)$ & & & $(278)$ & $(281)$ \\
TC2 & - & 3.21 & 4.76 & - & 4.28 & 4.07 & 3.78 \\
& & $(242.5)$ & $(294.5)$ & & $(236)$ & $(284)$ & $(294)$ \\
TC3 & 4.20 & 3.21 & 2.82 & 4.61 & 2.28 & - & - \\
& $(283)$ & $(242.5)$ & $(284.5)$ & $(282.5)$ & $(292)$ & &
\end{tabular}

It should be noted that these values are approximations of the ligand affinity. Indeed, error in our calculations due to the uncertainties involved in $\varepsilon$ determination and concentration of the solutions cannot be neglected. 